\title{
BED TEMPERATURE IN COMPOST BARNS TURNED WITH ROTARY HOE AND OFFSET DISC HARROW
}

\author{
Vania C. Mota ${ }^{1 *}$, Ednilton T. de Andrade ${ }^{2}$, Daniel F. Leite ${ }^{2}$ \\ ${ }^{1 *}$ Corresponding author. Fundação Universidade Federal de Rondônia- UNIR/ Campus de Ji-Paraná-RO, Brasil. \\ E-mail: vaniamota33@gmail.com | ORCID ID: https://orcid.org/0000-0001-8838-718X
}

\section{KEYWORDS}

aeration/oxygenation of the bed, dairy cattle, confinement, agricultural implements, spatial variability

\begin{abstract}
The success of confinement for dairy cattle in the compost barn model depends mainly on the management of the bed and consists of its turning. This paper characterises the spatial variability of the bed temperature in the compost barn confinement model, as well as verifying whether there was an effect on efficiency from turning the bed with different agricultural implements. The experiment was conducted during the summer and winter of 2016, with 8 days of collection in each period. Data were analysed with descriptive statistics methods and geostatistical modelling with semivariograms and kriging maps. The results of the t-test at a5\% significance level indicated that, after turning the bed with the plough or rotary hoe, the temperature values were significantly lower. There was an efficient on bed turning based on different agricultural implements. Spatial dependence was observed on the data, with a better adjustment given by a Gaussian model. Kriging maps allowed the characterization of the spatial variability of bed temperature and the visualization across the compost barn bed at the superficial layer and $0.15 \mathrm{~m}$ in depth.
\end{abstract}

\section{INTRODUCTION}

The confinement of dairy cattle in a compost barn (CB) is an alternative system of the Loose Housing system, where the animals stay loose and can walk freely inside a shed (rest area), influencing the welfare of the animals and, consequently, improving herd productivity levels (Black et al., 2013, Mota et al., 2018).

The success of the system depends mainly on the proper handling of the bed, which consists of its turning (Mota et al., 2017, Pilatti \& Vieira, 2017). The management of bedding material provides a dry, comfortable and healthy environment in which cows can stand and walk on a soft surface (Leso et al., 2013). The most common materials used as bedding are sawdust and wood chips (Pilatti \& Vieira, 2017). Small particulate materials such as finely processed straw, corn straw and wheat straw by-products can also be used. However, care should be taken with other types of bedding materials, such as sand, dry manure or soil (Galama et al., 2015).

The bed needs to be turned frequently and this can be observed in $\mathrm{CB}$ experiments for dairy cows reported in the literature of USA, Israel and Italy, among others (Leso et al., 2013, Black et al., 2014). The indicated average temperature should be between $54.4{ }^{\circ} \mathrm{C}$ and $65.5{ }^{\circ} \mathrm{C}$; the ideal bed humidity should range from 40 and $60 \%$ (Black et al., 2013), the $\mathrm{C}$ : $\mathrm{N}$ ratio should be $25-30: 1$ and the recommended animal density is 7.4-12.5 $\mathrm{m}^{2}$ cow $^{-1}$ (Galama et al., 2015). These values should be controlled because the entire surface of the resting area is covered with a deep bed material (soft bed), which is often agitated by agricultural implements to incorporate fresh manure into that material and increase water evaporation (Leso et al., 2013; Galama et al., 2015).

This process of bed turning is necessary for aeration to occur, and this maintains its aerobic condition. The process is usually carried out when the cows go to the milking parlour. Normally the agricultural implements used for bed turning are rotary hoes, subsoilers and offset disc harrows (Galama et al., 2015, Mota et al., 2017).

The harrow revolves the bed through the discs that are widely spaced, and when cutting the bedding material, the disc plough removes semi-circular sections that help in the incorporation of oxygen to that material. The subsoiler is used to turn the deeper layers of the bed, preventing the deeper regions from becoming anaerobic, while the rotating hoe does not turn the deeper parts of the bed, but breaks up the materials that become compacted. In this manner, this decomposition of aggregate particles promotes oxygenation and increases the surface action of the microorganisms present in the bed, causing an increase in composting efficiency (Mota et al., 2017).

\footnotetext{
${ }^{2}$ Universidade Federal de Lavras- UFLA/ Lavras - MG, Brasil. 
The composting bed $\mathrm{CB}$ refers to a mixture of faeces and urine produced by cows and organic bedding material (Leso et al., 2013). The biological activity generates heat and helps to dry the bedding material, and when this material begins to adhere to the cows, a clean material should be added to the bed (Galama et al., 2015).

Despite the increasing popularity of the CB system in Brazil, the scientific knowledge about this system is scarce and consequently requires more studies that can assist the milk producers in the process of decision making and planning. Therefore, it is important to encourage research related to dairy cattle facilities to maintain production at competitive levels. The objective of this research was to characterise the spatial variability of the bed temperature in the confinement system in the compost barn model, as well as to verify if there was an effect on bed turning efficiency based on different agricultural implements.

\section{MATERIAL AND METHODS}

The research was carried out in a compost barn confinement for dairy cattle, on a rural property in the municipality of Três Corações in the state of Minas Gerais. According to the Köppen international classification, the climate of the region is of the Cwa type, characterised by two well-defined seasons: a dry and cooler temperature, which extends from May to September, and a humid and warmer temperature from October to April. The average annual temperature is $20.2{ }^{\circ} \mathrm{C}$, and the annual rainfall is $1.401 \mathrm{~mm}$.

The experiment was conducted during the summer (VER treatment) and winter (INV treatment) of 2016 and was divided into 8 days of collection each for the VER and the INV. The data recording was carried out on January $10,13,17,20,24,27,31$ and February 3 for summer and on July 10, 13, 17, 20, 24, 27, 31 and August3 for winter.
Data were recorded using a model $3000 \mathrm{Kestrel}^{\circledR}$ brand portable data recorder that measured relative air humidity with $\pm 3 \%$ reading accuracy and temperature (accuracy \pm 1 ${ }^{\circ} \mathrm{C}$ ). The average air temperature and the external relative humidity of the shed during the data collection days were obtained with a model TTWH-1080 Instrutemp portable weather station with appropriate sensors to collect and store the data.

The shed in system compost barn (CB) with a Northwest to Southwest orientation, was $18.70 \mathrm{~m}$ wide by $50 \mathrm{~m}$ long, with a $4 \mathrm{~m}$ right foot, and a $6 \mathrm{~m}$ ridge. A $13 \times$ $50 \mathrm{~m}$ rest area with beds was divided into 3 lots (high milk production, average milk production and low milk production), separated by means of electric fencing, and this was the area used for analysis. The shed had a feeding corridor measuring $3 \times 50 \mathrm{~m}$ with a feeder (trough of bulk) throughout the length of the shed. There was another corridor measuring $2 \times 50 \mathrm{~m}$ with four drinking troughs measuring $0.50 \times 2 \mathrm{~m}$ (trapezoidal bottoms) with the capacity for $300 \mathrm{~L}$ of water. The shed also had three mineral troughs and five centralised fans at a height of $3.20 \mathrm{~m}$ in the Roster seating area (with six propellers). Each fan provided a flow of $48,000 \mathrm{~m}^{3}$ of air per hour.

The superficial temperature data $(\mathrm{S})$ of the $\mathrm{CB}$ bed were collected using a model GM-300 laser sight IR thermometer, with a temperature range of $-50-380{ }^{\circ} \mathrm{C}(-50$ at $\left.0{ }^{\circ} \mathrm{C}\right)+/-2{ }^{\circ} \mathrm{C}$ and $\left(0\right.$ to $\left.380{ }^{\circ} \mathrm{C}\right)+/-1.5{ }^{\circ} \mathrm{C}$. The bed temperature data for the $\mathrm{CB}$ at a depth of $0.15 \mathrm{~m}(\mathrm{P})$ were collected by a model ICEL Manaus TD-100 thermometer. There were 36 systematic samples collected for S and $\mathrm{P}$, before and after to be the bed was turned during the afternoon period, at the time of the second milking at 16:00 hours, in a regular grid (Yamamoto \& Landim, 2013) with 36 georeferenced points, distributed evenly along the shed with a $2.6 \times 5 \mathrm{~m}$ spacing (Figure1).

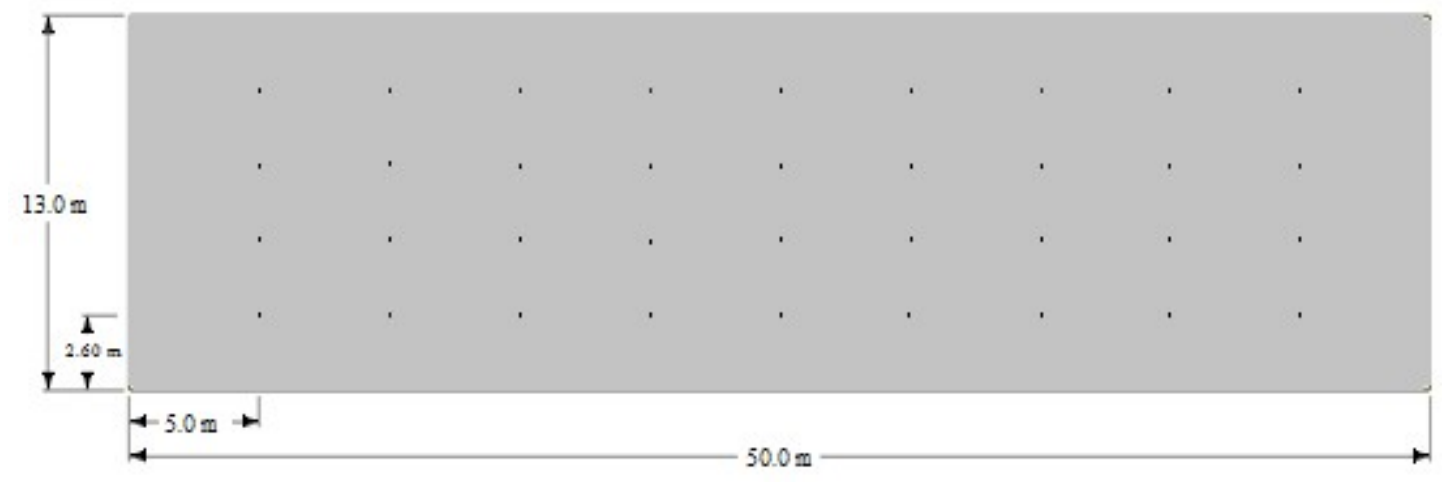

FIGURE1. Regular grid with 36 points used to record the bed superficial (S) and $0.15 \mathrm{~m}$ depth (P) temperatures.

The agricultural implements evaluated were a Santa Isabel model harrow with 28 discs angled of approximately $20^{\circ}$ that were set to a $0.20 \mathrm{~m}$ depth and a Selecta tilth model rotary hoe with seven cutting knives, with a depth adjustment of 0.0 $0.20 \mathrm{~m}$. There were eight days of sample collections in the summer of 2016, using the harrow for turning the bed (Figure $2 \mathrm{a}$ ) and eight days of collection in the winter of 2016 using the rotary hoe (Figure $2 \mathrm{~b}$ ). 


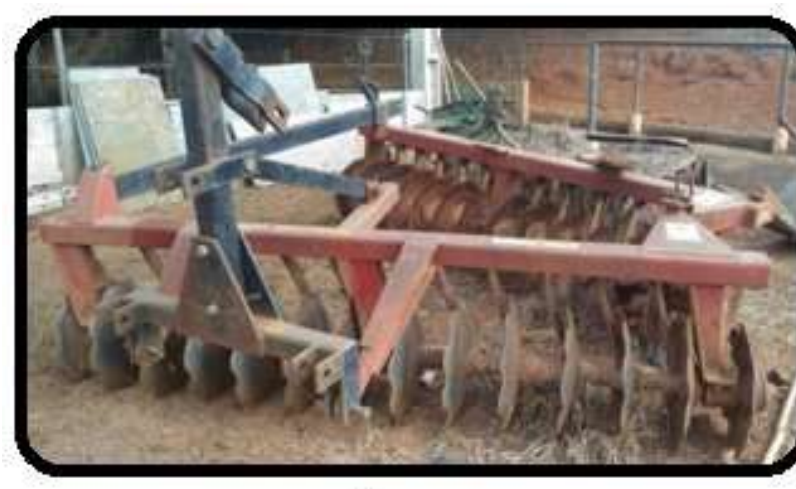

a

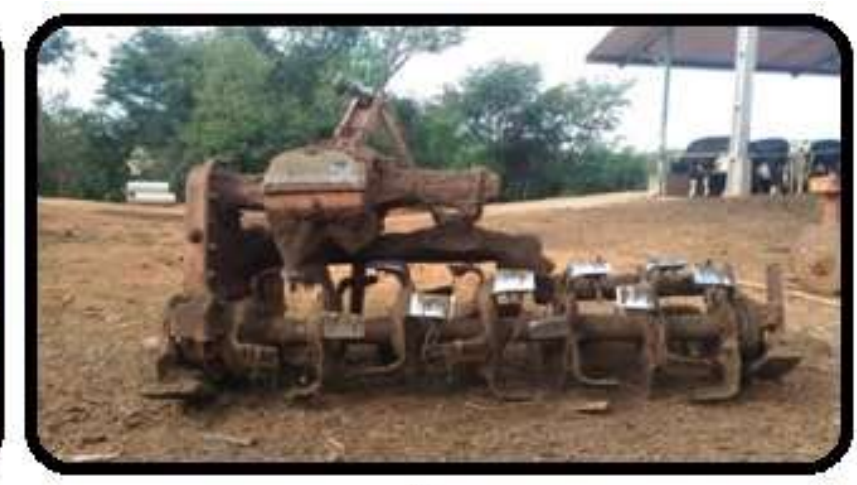

FIGURE2. Agricultural implements used to turn the bed. (a) disc harrow; (b) rotary hoe.

Initially, data for all collection days and the data average for the eight days each of summer and winter collection were analysed using descriptive statistics analysis procedures. The objective was to visualise the general behaviour of the data, determining position and dispersion measures, such as the mean, median, maximum (max) and minimum (min) values, standard deviation and coefficient of variation (Silva et al., 2012). Then the Shapiro Wilk test was applied to verify the normality of the data, the $\mathrm{F}$ test to compare two variances and the means test to compare paired data (Torman et al., 2012, Oliveira et al., 2014). There was a level of significance of $\alpha>0.05$ for all of the tests mentioned. Subsequently, only the data referring to the average of the eight days of summer collection and the average of the eight days of winter collection were submitted to geostatistical modelling to verify the spatial variability of the data. This was done through the construction of semivariograms and kriging maps.

The semivariograms were estimated using the classical Matheron estimators, given by (Yamamoto \& Landim, 2013):

$$
\hat{\gamma}(h)=\frac{1}{2 N(h)} \sum_{j=1}^{N(h)}\left[z\left(x_{j}+h\right)-z\left(x_{j}\right)\right]^{2}
$$

Where;

$N(h)$ is the number of possible pairs for the distance $h$;

$\hat{\gamma}(h)$ is the semivariance for a distance $h$;

$z\left(x_{j}\right)$ e $z\left(x_{j}+h\right)$ are the observations, surface temperature and temperature at $0.15 \mathrm{~m}$ separated by the vector $h$, and

$h$ is the separation distance of the observations.

For the adjustment of the theoretical semivariogram, the OLS method was used. The spherical, Gaussian, exponential and linear isotropic statistical models were compared according to Yamamoto \& Landim (2013), and they are defined by:

Spherical Model

$$
\gamma(h)=\left\{\begin{array}{c}
C_{0}+C\left[\frac{3}{2}\left(\frac{h}{a}\right)-\frac{1}{2}\left(\frac{h}{a}\right)^{3}\right] 0 \leq h \leq a \\
C_{0}+C h>a
\end{array}\right.
$$

Gaussian Model

$\gamma(h)=C_{0}+C\left(1-\exp \left(-3\left(\frac{h^{2}}{a^{2}}\right)\right)\right)$, se $0 \leq h \leq d$

Exponential Model

$$
\gamma(h)=\left\{\begin{array}{cl}
C_{0}+C\left[1-e^{\left[-\left(\frac{h}{a}\right)\right]}\right] & \text { para } 0<h<a \\
C_{0}+C & \text { para } h>a \\
0 & \text { para } h=a
\end{array}\right.
$$

Linear Model

$$
y(h)=\left\{\begin{array}{c}
C_{0}+\frac{C}{a h} 0 \leq h \leq a \\
C_{0}+C \quad h>a
\end{array}\right.
$$

Where;

$\gamma(h)$ is the semivariance for the distance $h$;

$C_{0}$ is the nugget effect;

$C_{0}+C$ is the sill;

$a$ is the range of spatial dependence, and

$\frac{c}{a}$ is the angular coefficient for $0 \leq h \leq a$.

From the set of results obtained by the classic estimators for the three models, their parameters were estimated, and the best model was selected according to the approximation of the value of the Akaike Criterion (AIC), given by:

$$
|A I C|=2 p+n \cdot \ln \left(\frac{R S S}{n}\right)
$$

Where;
$n$ is the number of observations;
$p$ is the number of parameters, and

$R S S$ is the sum of squares of residues, and the model with the lowest value of AIC was considered to be the best (Mota et al., 2008).

The relationship:

$$
\left(\frac{C o}{C o+C 1}\right) \times 100
$$

was used to evaluate the degree of spatial dependence (SD) of the variables the according to Cambardella et al. (1994), which classifies strong, moderate and weak SD 
values, when they have a nugget effect $<25 \%, 25-75 \%$, and $>75 \%$ of the sill, respectively. If the relation is greater than $100 \%$, the variable is considered spatially independent.

When spatial dependence occurs, the values not measured can be estimated without trends and with minimum variance in order to obtain information about the variable (through mapping). In these cases, it is necessary to use a geostatistical interpolator to generate a smoothed surface of the contour maps. Among the several interpolators in the literature, ordinary kriging has been used, which estimates everywhere, except where field observations are available, at which it reproduces the measured value (Yamamoto \& Landim, 2013). To verify if ordinary kriging adequately described the spatial variability of the variables studied, cross validation was used.
$\mathrm{R}^{2}$ (coefficient of determination), and the RSS (sum of squares of residues) were used as criteria for the crossvalidation. The best fit was reached when the correlation and determination coefficients were close to a value of 1 , and there was an adjacent zero intercept and an adjacent angular coefficient of 1 (Assumpção \& Hadlich, 2017). For RSS, smaller values correspond with better semivariogram models. The analyses were performed in $\mathrm{R}$ software (R Core Team, 2016) and GS+.

\section{RESULTS AND DISCUSSION}

The mean air temperature and the average relative air humidity inside the shed during the summer and winter collection days are shown in Figures 3 and 4.The mean values of external temperature in the summer and winter of 2016 were 26.5 and $21.2{ }^{\circ} \mathrm{C}$, respectively, and mean humidity values were $72 \%$ in summer and $58 \%$ in winter.

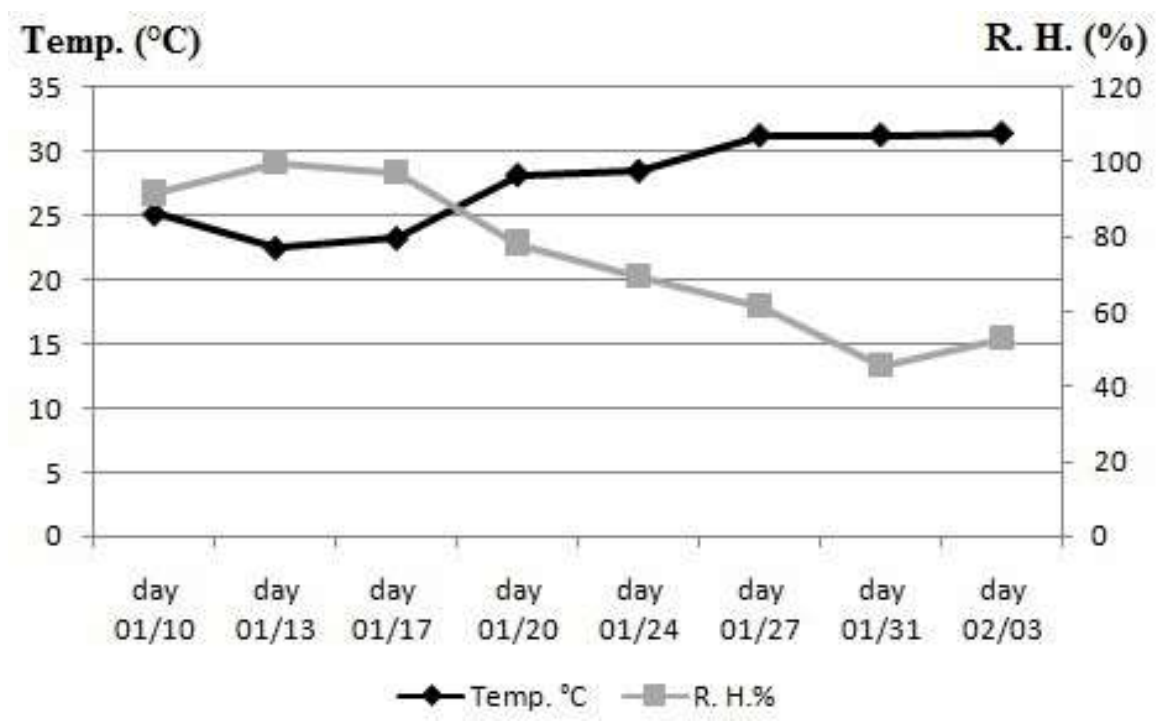

FIGURE 3. Variation of temperature $\left({ }^{\circ} \mathrm{C}\right)$ and relative humidity $(\%)$ inside the experimental shed in the summer period.

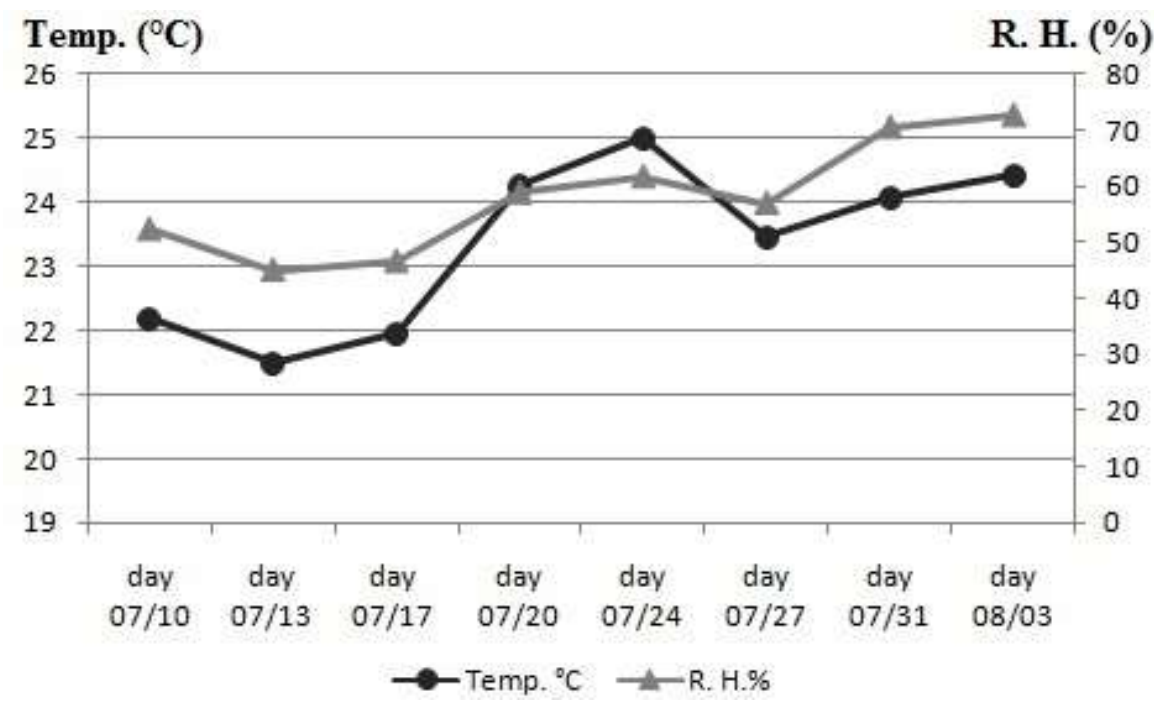

FIGURE 4. Variation of temperature $\left({ }^{\circ} \mathrm{C}\right)$ and relative humidity $(\%)$ inside the experimental shed during the winter period.

From the average temperature of the confinement bed in the compost barn model (Table 1), the maximum temperature at a depth of $0.15 \mathrm{~m}(\mathrm{P})$ obtained in summer 2016 before being turned was around $40.9^{\circ} \mathrm{C}$ and after turning around $41.8{ }^{\circ} \mathrm{C}$. This was below the ideal for this model of confinement. The average temperature indicated according to Leso et al. (2013) and Black et al. (2014) must be between 54.4 the $65.5^{\circ} \mathrm{C}$. The same was observed with the maximum temperature at the depth of $0.15 \mathrm{~m}(\mathrm{P})$, obtained in winter 2016, although it had higher values, 42.8 and $44.3{ }^{\circ} \mathrm{C}$, before and after turning, respectively. 
TABLE 1. Descriptive statistics and paired t-test results $(\alpha=0.05)$ for the mean values of the eight days of superficial $(\mathrm{S})$ and depth of $0.15 \mathrm{~m}(\mathrm{P})$ temperature collection of bedding in the compost barn.

\begin{tabular}{|c|c|c|c|c|}
\hline & \multicolumn{2}{|c|}{ (G - VER) } & \multicolumn{2}{|c|}{$(\mathrm{E}-\mathrm{INV})$} \\
\hline & Before & After & Before & After \\
\hline Min. (S) & 22.912 & 24.525 & 15.762 & 17.337 \\
\hline Min. (P) & 26.572 & 29.557 & 25.044 & 30.200 \\
\hline Max. (S) & 26.543 & 29.481 & 22.050 & 22.762 \\
\hline Max. (P) & 40.894 & 41.831 & 42.722 & 44.275 \\
\hline Median (S) & 24.387 & 26.140 & 17.925 & 19.250 \\
\hline Median (P) & 30.922 & 33.584 & 29.433 & 33.231 \\
\hline $\operatorname{Mean}(\mathrm{S})$ & 24.537 & 26.139 & 18.167 & 19.525 \\
\hline Mean (P) & 32.117 & 34.054 & 30.746 & 34.343 \\
\hline Standard deviation (S) & 0.864 & 1.277 & 1.401 & 1.301 \\
\hline Standard deviation $(\mathrm{P})$ & 3.554 & 2.677 & 4.230 & 3.555 \\
\hline Coefficient of Variation (S) & $3.52 \%$ & $4.88 \%$ & $7.71 \%$ & $6.66 \%$ \\
\hline Coefficient of Variation (P) & $11.06 \%$ & $7.86 \%$ & $13.75 \%$ & $10.35 \%$ \\
\hline Paired t-test (S) & \multicolumn{2}{|c|}{$5.817 \mathrm{e}^{-11^{*}}$} & \multicolumn{2}{|c|}{$5.775 \mathrm{e}^{-06^{*}}$} \\
\hline Paired t-test (P) & \multicolumn{2}{|c|}{$2.455 \mathrm{e}^{-14 *}$} & \multicolumn{2}{|c|}{$1.218 \mathrm{e}^{-13^{*}}$} \\
\hline
\end{tabular}

* significant at a $5 \%$ probability. Harrow in summer (G - VER) and rotating hoe in winter (E - INV).

The surface temperature was within the expected range, with higher values in summer and lower temperatures in winter, for both minimum (Min) and maximum (Max) temperature values before and after being turned, using the harrow in summer and the rotating hoe in winter. The coefficient of variation is a way of expressing the variability of the data, so when the value of the coefficient of variation was smaller the dispersion around the mean was smaller. The superficial and $0.15 \mathrm{~m}$ temperatures before and after the bed was turned had low coefficients of variation ( $\mathrm{CV} \leq 15 \%)$, indicating data homogeneity and low dispersion (Nazareno et al., 2016).

The data were normal, and the variances were homogeneous according to the $F$ test for the VER treatment, so the t-test was applied to the paired samples. The results indicated that there was a significant difference between the means of the two samples, and we concluded that the differences in CB bed temperature before and after being rotated with the harrow were significant.

For the rotational hoe used in the winter, the data also had a normal distribution according to the ShapiroWilk normality test, and the variances were homogeneous, so the paired t-test was used.

The results of the t-test at the significance level of $5 \%$ indicated that, after turning the bed with the harrow or rotating hoe, the values of the temperatures were significantly lower, indicating that there was an efficiency effect on the bed turning from these agricultural implements.
The bedding material needs to be turned daily for aeration to occur and to maintain aerobic conditions. Biological activity produces heat that assists in drying the bed, and when this material begins to adhere to cows, a clean, dry material should be added (Galama et al., 2015).

Mota et al. (2018), states that turning the material of the bed properly reduces the moisture and increases bed temperature, improving the composting process, with reductions in pathogenic microorganisms.

From the results of the geostatistical modelling in summer (for the theoretical models and estimated parameters of the semivariograms), a strong spatial dependence was observed for temperature at the surface and at the depth of $0.15 \mathrm{~m}$ of the confinement bed for dairy cattle in the compost barn model in the summer of 2016 (Table 2). The exception was the linear model that showed a weak spatial dependence for the surface temperature before being turned and a moderate dependence for the other variables.

For the superficial temperature in summer, there was a better fit for the "Gaussian" model, with lower AIC and RSS values when compared with the spherical, exponential and linear models. As for temperature at the depth of $0.15 \mathrm{~m}$ during the summer of 2016, the results were similar. A better adjustment of the "Gaussian" model was observed, with a high degree of spatial dependence, or the semivariograms had a nugget effect equal to or less than $25 \%$ of the level and with lower AIC and RSS values while having higher $\mathrm{R}^{2}$ values. 
TABLE 2. Estimation of the nugget effect parameters $\left(C_{0}\right)$, sill $\left(C_{0}+C_{1}\right)$, range $(a)$, approximation of value of the Akaike Criterion (AIC), degree of spatial dependence (SD), coefficient of determination $\left(\mathrm{R}^{2}\right)$ and the sum of squares of residues (RSS) of the "spherical" (Sph.), "Gaussian" (Gaus.), "exponential" (Exp.) and "linear" (Lin.) adjusted to the experimental semivariograms, relative to the superficial and $0.15 \mathrm{~m}$ depth temperatures of the confinement bed for dairy cattle in the compost barn model in the summer of 2016.

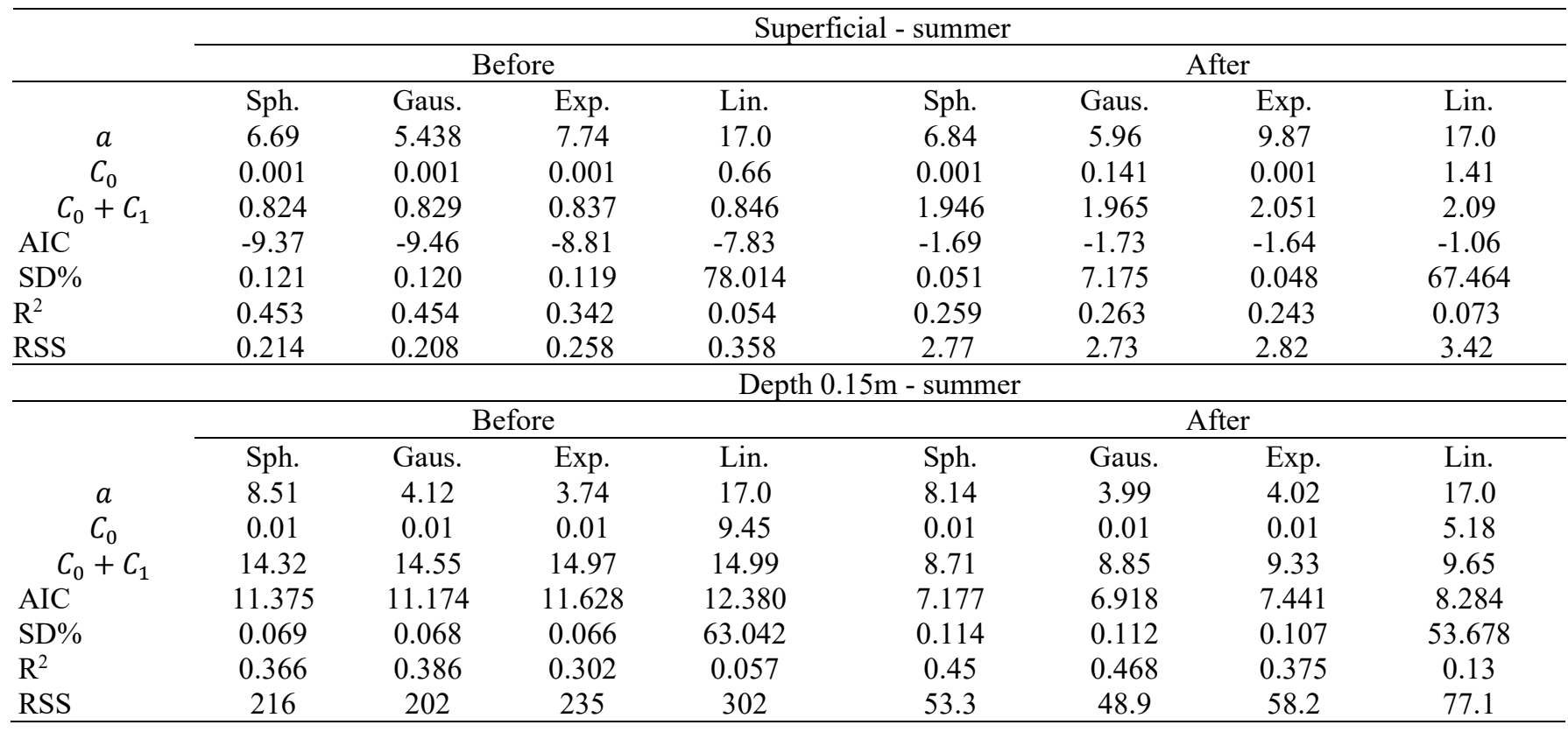

The values of AIC and SD and the estimates of the parameters of the theoretical semivariogram models for the surface temperature and temperature in the depth of $0.15 \mathrm{~m}$ of the confinement bed for dairy cattle in the compost barn model in the winter of 2016 are shown in Table 3.
A better fit of the "Gaussian" model was observed, with moderate spatial dependence on before and after surface temperature and a strong degree of spatial dependence for the temperature at a depth of $0.15 \mathrm{~m}$.

TABLE 3. Estimation of the nugget effect parameters $\left(\mathrm{C}_{0}\right)$, sill $\left(\mathrm{C}_{0}+\mathrm{C}_{1}\right)$, range $(a)$, approximation of value of the Akaike Criterion (AIC), degree of spatial dependence (SD), coefficient of determination $\left(\mathrm{R}^{2}\right)$ and the sum of squares of residues (RSS) of the "spherical" (Sph.), "Gaussian" (Gaus.), "exponential" (Exp.) and "linear" (Lin.) models adjusted to the experimental semivariograms, relative to the superficial temperature and temperature in the $0.15 \mathrm{~m}$ depth of the confinement bed for dairy cattle in the compost barn model in the winter of 2016.

\begin{tabular}{|c|c|c|c|c|c|c|c|c|}
\hline & \multicolumn{8}{|c|}{ Superficial - winter } \\
\hline & \multicolumn{4}{|c|}{ Before } & \multicolumn{4}{|c|}{ After } \\
\hline & Sph. & Gaus. & Exp. & Lin. & Sph. & Gaus. & Exp. & Lin. \\
\hline$a$ & 33.60 & 16.49 & 20.15 & 17.0 & 30.71 & 15.63 & 23.78 & 17.00 \\
\hline$C_{0}$ & 0.552 & 0,921 & 0.41 & 0.591 & 0.369 & 0.558 & 0.314 & 0.3969 \\
\hline$C_{0}+C_{1}$ & 3.24 & 3.32 & 3.83 & 2.47 & 1.642 & 1.698 & 2.25 & 1.34 \\
\hline AIC & -3.30 & -3.37 & -3.21 & -3.34 & -7.31 & -7.34 & -7.26 & -7.34 \\
\hline $\mathrm{SD} \%$ & 17.04 & 27.74 & 10.70 & 23.93 & 22.47 & 32.86 & 13.95 & 29.61 \\
\hline $\mathrm{R}^{2}$ & 0.56 & 0.57 & 0.55 & 0.56 & 0.553 & 0.559 & 0.547 & 0.558 \\
\hline \multirow[t]{4}{*}{$\underline{\mathrm{RSS}}$} & 1.62 & 1.58 & 1.67 & 1.60 & 0.426 & 0.421 & 0.432 & 0.421 \\
\hline & \multicolumn{8}{|c|}{ Depth $0.15 \mathrm{~m}$ - winter } \\
\hline & \multicolumn{4}{|c|}{ Before } & \multicolumn{4}{|c|}{ After } \\
\hline & Sph. & Gaus. & Exp. & Lin. & Sph. & Gaus. & Exp. & Lin. \\
\hline$a$ & 10.27 & 8.07 & 13.83 & 17.00 & 8.07 & 6.72 & 10.83 & 17.00 \\
\hline$C_{0}$ & 0.01 & 0.01 & 0.01 & 11.84 & 0.01 & 0.01 & 0.01 & 9.69 \\
\hline$C_{0}+C_{1}$ & 23.81 & 23.91 & 25.26 & 26.22 & 15.31 & 15.49 & 16.02 & 16.65 \\
\hline $\mathrm{AIC}$ & 10.94 & 10,44 & 11.68 & 13.08 & 6.69 & 6.01 & 7.781 & 9.56 \\
\hline $\mathrm{SD} \%$ & 0.042 & 0.042 & 0.039 & 45.16 & 0.065 & 0.064 & 0.062 & 58.19 \\
\hline $\mathrm{R}^{2}$ & 0.67 & 0.70 & 0.57 & 0.24 & 0.76 & 0.78 & 0.60 & 0.19 \\
\hline RSS & 187.0 & 158.0 & 239.0 & 381.0 & 45.3 & 36.1 & 65.2 & 118.0 \\
\hline
\end{tabular}


The results obtained from the analysis of bed temperature behaviour corroborate with those presented by Carvalho et al. (2011) in his research. These authors analysed the quality of reused chicken beds and air in commercial production aviaries with different ventilation systems and typology through geostatistical analysis. They identified spatial dependence, characterised by adjustment of the theoretical models of semivariograms, and with better adjustment of the spherical model to the bed temperature of the aviary, the authors concluded that the

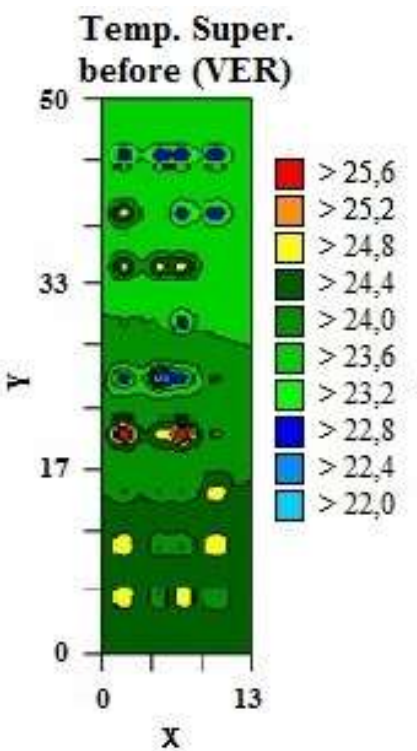

(a)

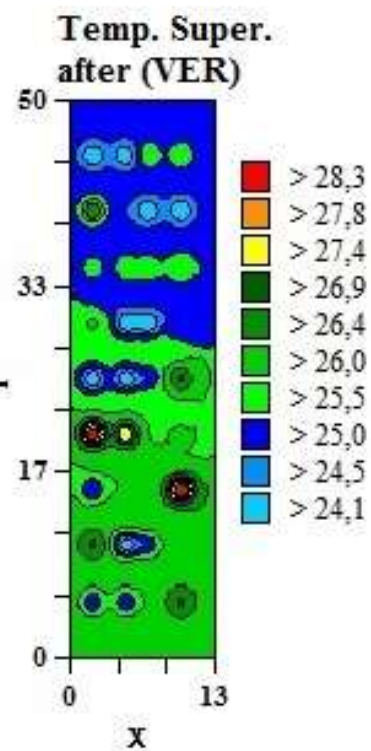

(b)

geostatistical analysis assisted in the identification of critical points in the control of the environments studied.

Figure 5 and 6 show the bed superficial temperature distribution and the temperature at $0.15 \mathrm{~m}$ depth for the VER and INV treatments, using the harrow and the rotary hoe, respectively. In the surface temperature of the bed in the treatment summer (Figure 5) before and after being turned by the grid harvester, it was observed that there was a small change, with higher values in proximity to the electric fence that separates the pickets with small islands of temperature above $25.6{ }^{\circ} \mathrm{C}$.

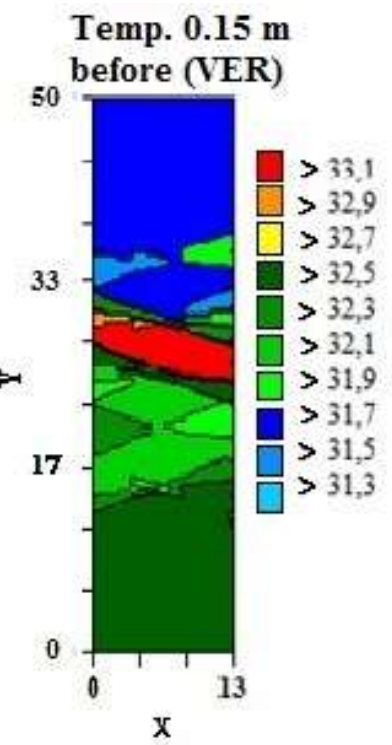

(c)

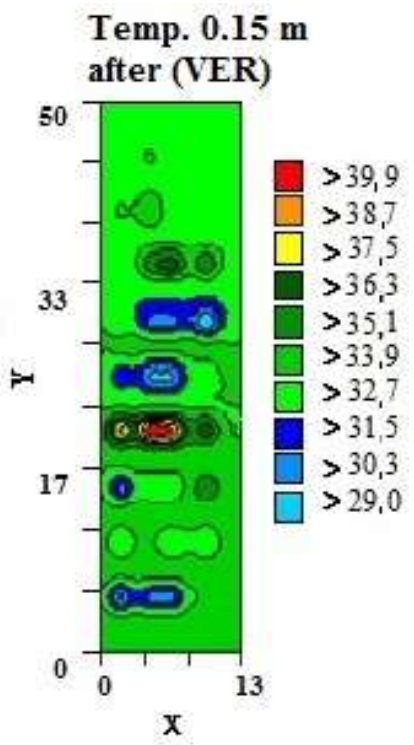

(d)

FIGURE 5. Maps of kriging for summer 2016. (a) surface temperature of the bed before being stirred, (b) bed surface temperature after turning, (c) bed $0.15 \mathrm{~m}$ temperature before turning and (d) $0.15 \mathrm{~m}$ temperature of the bed after it was turned.

For the temperatures at $0.15 \mathrm{~m}$ depths, lower temperatures were observed in the region near the exit of the shed, where the afternoon sun was not predominant, which indicated that the position of the installation influenced the homogeneity of the bed temperature. After

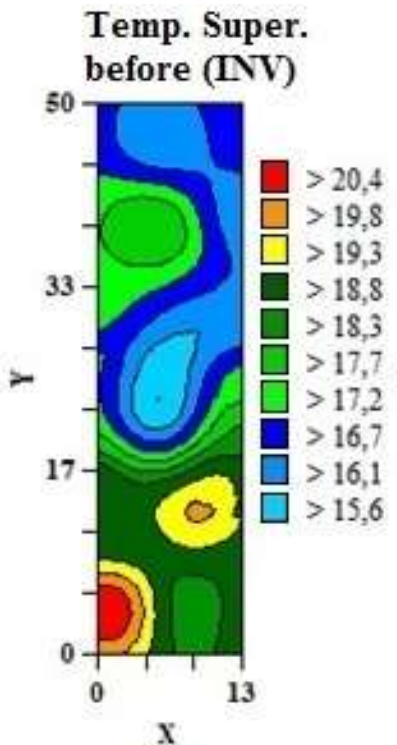

(a)

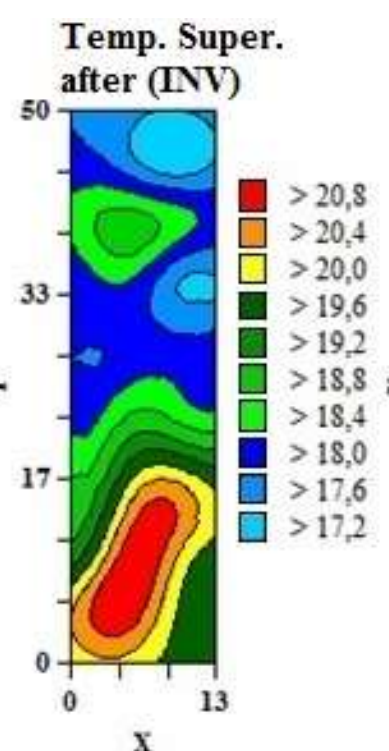

(b)

turning, with the stirring of the bed material, there was a greater homogeneity of temperature throughout the shed, maintaining the highest temperature near the picket divisions, with temperatures above $39.9^{\circ} \mathrm{C}$.

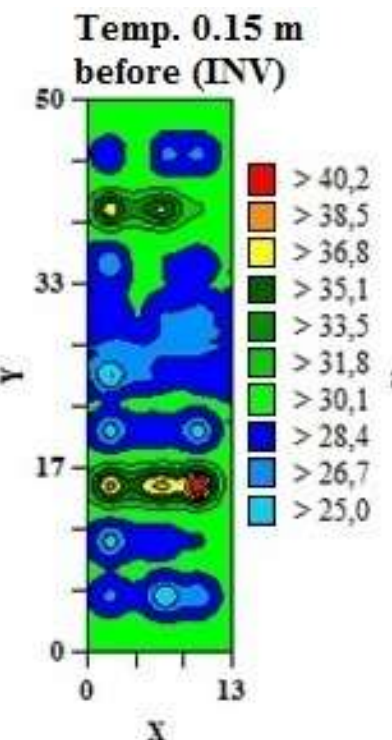

(c)

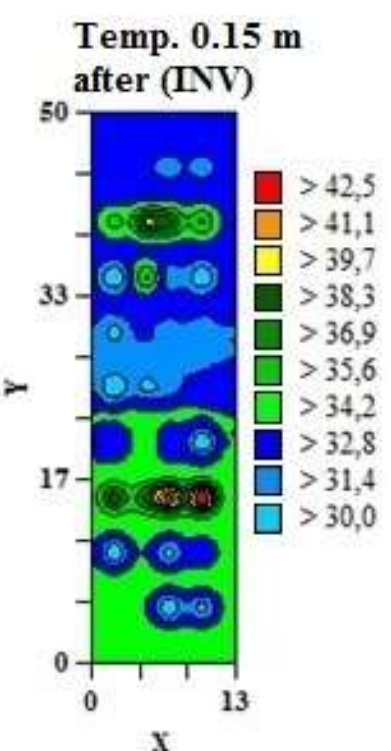

(d)

FIGURE 6. Maps of winter kriging of 2016.(a) surface temperature of the bed before being stirred (b), bed surface temperature after turning (c) $0.15 \mathrm{~m}$ bed temperature before turning and (d) $0.15 \mathrm{~m}$ temperature of the bed after it was turned. 
In winter (Figure 6), the surface temperature had higher values near the entrance with islands (red dots on the map) of $20.4{ }^{\circ} \mathrm{C}$, which indicated that the afternoon sun influenced this temperature. Additionally, in the other part of the shed the afternoon surplus and dominant surface temperatures were higher than $15.6{ }^{\circ} \mathrm{C}$, and, even after turning with the rotating hoe, the difference at that point was small, increasing to $17.2{ }^{\circ} \mathrm{C}$. While in the winter, the temperatures at $0.15 \mathrm{~m}$ had presented higher values $\left(42.5^{\circ}\right.$ C) when compared to the summer, with islands of temperature also in the divisions of the pickets, which are the divisions with the electric fence (the colours red and orange in the map).

\section{CONCLUSIONS}

Geostatistics allowed us to characterise the variability and spatial dependence of the surface and 0.15 $\mathrm{m}$ depth temperatures of the bed in the compost barn confinement during the summer and winter seasons, for milk cattle. The turning of the bed by means of the harrow and rotary hoe enabled the reduction of temperature in both assessment layers.

\section{ACKNOWLEDGMENTS}

The authors thank the Coordenação de Aperfeiçoamento de Pessoal de Ensino Superior (CAPES)for financial support.

\section{REFERENCES}

Assumpção HCP, Hadlich GM (2017) Estatística descritiva e estacionaridade em variáveis geoquímicas ambientais. Engenharia Sanitaria e Ambiental 22(4):671677. DOI: http://dx.doi.org/10.1590/S1413-41522017142739

Black RA, Taraba JL, Day GB, Damasceno FA, Bewley JM. (2013) Compost bedded pack dairy barn management, performance, and producer satisfaction. Journal of Dairy Science 96:8060-8074.

Black RA, Taraba JL, Day GB, Newman MC, Akers KA, Wood CL, McQuerry KJ, Bewley JM(2014) The relationship between compost bedded pack performance, management, and bacterial counts. Journal of Dairy Science 97:2669- 2679. DOI: http://dx.doi.org/10.3168/jds.2013-6779

Cambardella CA, Moorman TB, Novak J, Parkin TB, Karlen DL, TurcoR, Konopka AE (1994). Field scale variability of soil properties in Central Iowa soils. Soil Science Society of America Journal 58(5):1501-1511. DOI: http://dx.doi.org/10.2136/sssaj1994.03615995005800050033x

Carvalho TMR de, Moura DJ de, Souza ZM de, Souza GS de, Bueno LG de F (2011) Qualidade da cama e do ar em diferentes condições de alojamento. Pesquisa Agropecuária Brasileira 46(4):351-361.
Galama PJ, Boer HC de, Dooren HJC van, Ouweltjes W, Driehuis K (2015) Aspects of ten bedded pack dairy barns in The Netherlands, Wageningen. Available:

http://library.wur.nl/WebQuery/wurpubs/489726. Accessed: Aug 18, 2017.

Leso L, Uberti M, Morshed W, Barbari M (2013) Survey of Italian compost dairy barns Journal of Agricultural Engineering 44(3):120-124. DOI: http://dx.doi.org/10.4081/jae.2013.e17

Mota VC, Lima RR de, Alves M de C, Oliveira MS, Carvalho LG de (2008). Dependência temporal da precipitação pluvial e da temperatura do arem Juiz de Fora, MG, por meio de análises geoestatísticas. Revista Brasileira de Agrometeorologia 16(3):249-258.

Mota VC, Campos AT, Damasceno FA, Resende EA de M, Rezende CP do A, Abreu LR de, Vareiro T (2017) Confinamento para bovinos leiteiros: Histórico e características. PUBVET 11(5):433-442. DOI: http://dx.doi.org/10.22256/pubvet.v11n5.433-442

Mota VC, Damasceno FA, Leite DF (2018) Fuzzy clustering and fuzzy validity measures for knowledge discovery and decision making in agricultural engineering. Computers and Electronics in Agriculture 150:118-124. DOI: https://doi.org/10.1016/j.compag.2018.04.011

Nazareno AC, Silva IJO da, Fernandes DPB (2016) Prediction of mean surface temperature of broiler chicks and load microclimate during transport. Engenharia Agrícola 36(4):593-603.

Oliveira FL de, Siqueira JC de, Santos J da C dos, Pereira WG (2014) Equações de predição da energia digestível de ingredientes protéicos de origem vegetal utilizados em rações para tilápias. Cadernos Pesquisa 21:1-9.

Pilatti JA, Vieira FMC (2017) Environment, behavior and welfare aspects of dairy cows reared in compost bedded pack barns system. Journal Animal Behaviour Biometeorology 15:97-105.

R Development Core Team (2016) R: A language and environment for statistical computing. Vienna, R Foundation for Statistical Computing. Available: http://www.R-project.org.

Silva M da S, Pandorfi H, Almeida GLP de, Guiselini C, Caldas AM, Jacob AL (2012) Análise espacial das condições térmicas do ambiente pré-ordenha de bovinos leiteiros sob regimes de climatização. Revista Brasileira Agrícola e Ambiental 16(8):903-909. DOI: http://dx.doi.org/10.1590/S1415-43662012000800013

Torman VBL, Coster R, Riboldi J (2012) Normalidade de variáveis: métodos de verificação e comparação de alguns testes não-paramétricos por simulação. Revista HCPA 32(2):227-234.

Yamamoto JK, Landim PMB (2013) Geoestatística: conceitos e aplicações. São Paulo, Editora Oficina de Letras, 215p. 